\title{
Economic Empowerment of Rural Farm Women through Mushroom Production - A Case Study of Patna District, India
}

\author{
B.D. Singh ${ }^{1}$, Mrinal Verma ${ }^{1}$, Rajeev Kumar ${ }^{1}$, Prakash Chandra Gupta ${ }^{1}$ and Aditya ${ }^{2 *}$ \\ ${ }^{1}$ Krishi Vigyan Kendra, Agwanpur, Barh, Patna-803214, Bihar, India \\ ${ }^{2}$ B.A.U., Sabour, Bhagalpur, Bihar, India \\ *Corresponding author
}

\section{A B S T R A C T}

The study revealed that exposure to training, Front Line Demonstration, Technical Bulletin and Extension literature etc. had increased the knowledge of rural farmwomen regarding

\section{Keywords}

Mushroom, Rural

farmwomen,

Empowerment

Article Info

Accepted:

04 April 2018

Available Online:

10 May 2018 all the subcomponents of mushroom production and empower a woman is to empower next generation. There is an urgent need to make rural farm women economically independent and we cannot think of a better alternative than entrepreneurship development. In order to bring a change to this situation, Krishi Vigyan Kendra, Barh, Patna conducting Front Line Demonstration and organizing Vocational Training based on empowering rural farm women through entrepreneurship development. This can prove a suitable approach for economic empowerment. It is the only possible way to empower rural farmwomen by capacity building and skill. To assess the social acceptability a structured interview schedule has been prepared and survey was carried out in 100 randomly selected rural farm women of Patna District. Economic viability of the mushroom production as the mushroom yield ranged from 80 to $120 \mathrm{~kg} / 100 \mathrm{~kg}$ wheat straw and total income from $100 \mathrm{~kg}$ wheat straw ranged from Rs. 6400-12000 with net profit of Rs.4650-12000 in six months. Sixty one percent farm women socially accepted the mushroom production as an income generation activity.

\section{Introduction}

Empower a woman to empower next generation. Women constitute almost fifty percent of the entire population. Rural farm women are invisible in statistics while women are extensively involved in agricultural activities. Rural farm women play a crucial role in agricultural development and allied fields including crop production, livestock production, horticulture, post-harvest operations, fisheries and mushroom production etc. In addition to their role in agricultural production, women are gainfully employed in agri-based allied activities like dairying, animal husbandry, poultry, goatery, rabbit rearing, beekeeping, mushroom production, floriculture, horticulture, fruit preservation, post-harvest technology, value added food products etc. Their roles range from managers to landless labourer. The total agricultural labourers are 106.77 million out of which $46.31 \%$ are female worker (Pradhan and Sadangi, 2008) but are less likely to secure favourable outcomes for themselves in 
household decision making process (Amartya Sen, 2007). UNDP report indicates that while $67 \%$ of the world's work is done by women, only $10 \%$ of global income is earning by women and a mere $1 \%$ of global property is owned by women (Singh and Kumar, 2007).

Mushroom cultivation is a women friendly profession. Mushroom growing is one agricultural activity in which rural farm women can play a pivotal role without sacrificing their household responsibilities. Mushroom cultivation is simple, low cost, and suitable for rural areas, is less labor intensive and can provide employment in both the semiurban and rural areas. Mushroom cultivation will improve the socio-economic condition of farmers, families and solve employment problems of both literate and illiterate, especially rural farm women. Mushroom cultivation as an entrepreneurship development among rural farm women could prove a suitable approach for economic empowerment. This is the only possible way to empower rural farm women by providing resource support such as organizational development, vocational training, skill upgradation training, entrepreneurship development training, financial linkages and technical support so that they will get employment/self-employment and earn good incomes. The rural farm women can adopt agriculture based agribusiness on individual or group level and raise their income and employment opportunities which make them economically and socially empowered. Mushroom production, Bee-keeping, Dairy, Goatery, Seed production, cultivation of fruits, flower and vegetables can increase the income of rural farmers upto $70-80 \%$. Therefore, there is a urgent need to make rural farm women's economically and socially independent.

In this above context, an attempt has been made to introduce the mushroom production as an income raising and employment generating activity. Mushroom production is a women friendly profession. This is one agricultural activity where rural farmwomen can play a major role without sacrificing the household responsibilities. This kind of cultivation is low cost, simple and ideally suitable for rural areas. Mushroom cultivation has the potential ability to improve the economic as well as social condition of rural farm women. To bring a change in this situation following objectives were taken for present study:

To assess the economic viability of mushroom production by rural women.

To assess the social acceptability of mushroom production by rural women.

\section{Materials and Methods}

Krishi Vigyan Kendra Barh, Patna, conducting Front Line Demonstration and organizing Vocational training on mushroom production. Under Front Line Demonstration, farm women were given mushroom spawn, treated polythene bags and fungicide. To assess the social acceptability a structured interview schedule was prepared and survey was conducted among 100 randomly selected rural farm women from the Barhblock of Patna district.

\section{Results and Discussion}

The KVK intervention on mushroom production through training and demonstration during 2012-2017 is given in Table 1 showed that total 380 farm women were trained for mushroom production and 350 front line demonstrations were conducted during 20122017. One technical bulletin and one extension folder was also prepared to create awareness about consumption and production of mushroom. 
Table.1 Extension activity on mushroom production (2012-2017)

\begin{tabular}{|l|l|c|c|}
\hline Sl. No. & Extension Activity & Year & No. of Beneficiary \\
\hline 1. & Training & $2012-2017$ & 380 \\
\hline 2. & Front Line Demonstration & $2012-2017$ & 380 \\
\hline 3. & Technical Bulletin & $2012-2017$ & 2000 \\
\hline 4. & Extension Literature & $2012-2017$ & 1500 \\
\hline
\end{tabular}

Table.2 Economic analysis of mushroom production

\begin{tabular}{|l|l|c|c|c|c|}
\hline Sl. No. & Year & $\begin{array}{c}\text { Yield/100 kg } \\
\text { wheat straw }\end{array}$ & Cost (in Rs.) & Income (in Rs.)* & $\begin{array}{c}\text { Net Profit (in } \\
\text { Rs.) }\end{array}$ \\
\hline 1. & $2012-2013$ & 80 & 1750 & 6400.00 & 4650.00 \\
\hline 2. & $2013-2014$ & 90 & 2000 & 7200.00 & 5200.00 \\
\hline 3. & $2014-2015$ & 100 & 2500 & 8000.00 & 5500.00 \\
\hline 4. & $2015-2016$ & 110 & 3000 & 11000.00 & 9000.00 \\
\hline 5. & $2016-2017$ & 120 & 3000 & 12000.00 & 12000.00 \\
\hline
\end{tabular}

*Rate of mushroom during 2012-15 was Rs.80 / kg

*Rate of mushroom during 2015-17 was Rs. 100 / kg

Table.3 Social acceptability of mushroom production

\begin{tabular}{|c|c|c|c|c|c|c|c|c|}
\hline \multirow[t]{2}{*}{ S. No. } & \multirow[t]{2}{*}{ Statement } & \multicolumn{2}{|c|}{ Yes } & \multicolumn{2}{|l|}{ No } & \multicolumn{2}{|c|}{ Uncertain } & \multirow[t]{2}{*}{ Total } \\
\hline & & No & $\%$ & No & $\%$ & No & $\%$ & \\
\hline 1 & Mushroom is a Pure vegetarian food & 71 & 71 & 22 & 22 & 07 & 07 & 100 \\
\hline 2 & It has high nutritive value & 58 & 58 & 26 & 26 & 16 & 16 & 100 \\
\hline 3 & $\begin{array}{l}\text { Mushroom strengthens our immune } \\
\text { system }\end{array}$ & 47 & 47 & 28 & 28 & 25 & 25 & 100 \\
\hline 4 & It is a profitable enterprises & 81 & 81 & 16 & 16 & 03 & 03 & 100 \\
\hline 5 & $\begin{array}{l}\text { Its production helps to use waste farm } \\
\text { produce }\end{array}$ & 55 & 55 & 29 & 29 & 16 & 16 & 100 \\
\hline 6 & It is good for environment & 43 & 43 & 31 & 31 & 26 & 26 & 100 \\
\hline 7 & $\begin{array}{l}\text { Mushroom helps in restoring pollution- } \\
\text { damaged habitats }\end{array}$ & 48 & 48 & 33 & 33 & 19 & 19 & 100 \\
\hline 8 & $\begin{array}{l}\text { It requires lesser time and space for its } \\
\text { production }\end{array}$ & 88 & 88 & 10 & 10 & 02 & 02 & 100 \\
\hline 9 & It requires less labour & 82 & 82 & 13 & 13 & 05 & 05 & 100 \\
\hline 10 & It requires less capital & 78 & 78 & 12 & 12 & 10 & 10 & 100 \\
\hline 11 & Its processing is very easy & 76 & 76 & 17 & 17 & 07 & 07 & 100 \\
\hline 12 & Fetching high price & 90 & 90 & 08 & 08 & 02 & 02 & 100 \\
\hline \multirow[t]{2}{*}{13} & Its recipe preparation is easy & 57 & 57 & 23 & 23 & 20 & 20 & 100 \\
\hline & Mean & 67 & 67 & 21 & 21 & 12 & 12 & 100 \\
\hline
\end{tabular}


The data in Table 2 indicated that the economic viability of the mushroom production as the mushroom yield ranged from $80-120 \mathrm{~kg} / 100 \mathrm{~kg}$ wheat straw and total income from $100 \mathrm{~kg}$ wheat straw ranged from Rs.6400-12000 with net profit of Rs. 4650-12000 in the six months i.e. October to March (Bhatt et al., 2011).

Table 3 indicated the social acceptability of mushroom production. $90 \%$ farm women agreed with the fact that mushroom is a remunerative enterprises, $80 \%$ rural women agreed with that mushroom production require lesser time and space. $82 \%$ percent farm women believed that labour requirement minimum in mushroom production while $81 \%$ percent farm women believed that mushroom is a profitable enterprise. On an average $67 \%$ farm women socially accepted the mushroom production as an income generation activity. Kapoor and Behl (1983) and Chauhan and Sood (1992) also reported that mushroom growing has been appreciated as a technically feasible and profitable venture and widely accepted by the researchers as a good venture for his income, employment generation and rural development.

It is concluded that mushroom production for economic empowerment of farm women is a profitable activity. There is an urgent need to impart technical knowhow to women in order to adopt mushroom production as an income generating activity for enhancing additional income of their family. Rather it is a boon for poverty alleviation as reported by Chiroro (2004). Indian agriculture cannot improve without making the women equal partners in its development efforts. As women play a pivotal role in many facets of the composite farming system practiced by farm families. Therefore, to improve the position of women work force it is necessary to improve their production potential by treating them as important economic sectors not as dependent member of the family (Rath et al., 2007).

\section{References}

Amartya, Sen, 2007. Rural development and women empowerment.

Bhatt, N., Singh, R.K. and Kumar, A. 2011. Adheekaaykedetiswate button kikheti, Phal-Pool, Sept-Oct. pp. 29-36.

Chauhan, S.K. and Sood, R. P. 1992. Economic of production and marketing of mushroom in Kangra district, Himachal Pradesh. Indian J. Agriculture Marketing. 6(2): 4449.

Chiroro, Canford K. 2004. Poverty alleviation by mushroom growing in Zimbabwe. International j. Mushroom Res. and Dev. 3(2): 97-98.

Kapoor, P. and Behl, N. 1983. Cultivation of button mushroom - Gram Prodyogiaka. 3(2): 101.

Mir M. Amin, 2008. Entrepreneurship development: An approach to economic empowerment of women, Kurukshetra, pp. 29-32.

Pradhan, D. and Sadangi, B.N. 2008. Improving child care practice for the families of women agricultural labourers, Kurukshetra. 56(11): 36-39.

Rath, N. C., Das, L., Mishra, S. K. and Lenka, S. 2007, Social and Institutional Framework for Mainstreaming Women in Agriculture. Kurukshetra. 55(5): 21-28.

Sepat, I. and Kumari, U. 2007. Rural development and women empowerment, Kurukshetra. 55(5): 3-8.

Singh, I. and Kumari, U. 2007. Rural development and women empowerment, Kurukshetra. 55(5): 3-8.

Suneetha, R. 2007. Is DWCRA progamme empowering the rural women, Kurukshetra. 55(5): 17-20.

\section{How to cite this article:}

Singh, B.D., Mrinal Verma, Rajeev Kumar, Prakash Chandra Gupta and Aditya. 2018. Economic Empowerment of Rural Farm Women through Mushroom Production - A Case Study of Patna District. Int.J.Curr.Microbiol.App.Sci. 7(05): 348-351. doi: https://doi.org/10.20546/ijcmas.2018.705.044 